\title{
Integrative genomic analysis identifies a role for intercellular adhesion molecule 1 in childhood asthma
}

Citation for published version (APA):

Klaassen, E. M. M., van de Kant, K. D. G., Jöbsis, Q., Penders, J., van Schooten, F. J., Quaak, M., den Hartog, G. J. M., Koppelman, G. H., van Schayck, C. P., van Eys, G., \& Dompeling, E. (2014). Integrative genomic analysis identifies a role for intercellular adhesion molecule 1 in childhood asthma. Pediatric Allergy and Immunology, 25(2), 166-172. https://doi.org/10.1111/pai.12187

Document status and date:

Published: 01/01/2014

DOI:

10.1111/pai.12187

Document Version:

Publisher's PDF, also known as Version of record

Document license:

Taverne

Please check the document version of this publication:

- A submitted manuscript is the version of the article upon submission and before peer-review. There can be important differences between the submitted version and the official published version of record.

People interested in the research are advised to contact the author for the final version of the publication, or visit the DOI to the publisher's website.

- The final author version and the galley proof are versions of the publication after peer review.

- The final published version features the final layout of the paper including the volume, issue and page numbers.

Link to publication

\footnotetext{
General rights rights.

- You may freely distribute the URL identifying the publication in the public portal. please follow below link for the End User Agreement:

www.umlib.nl/taverne-license

Take down policy

If you believe that this document breaches copyright please contact us at:

repository@maastrichtuniversity.nl

providing details and we will investigate your claim.
}

Copyright and moral rights for the publications made accessible in the public portal are retained by the authors and/or other copyright owners and it is a condition of accessing publications that users recognise and abide by the legal requirements associated with these

- Users may download and print one copy of any publication from the public portal for the purpose of private study or research.

- You may not further distribute the material or use it for any profit-making activity or commercial gain

If the publication is distributed under the terms of Article $25 \mathrm{fa}$ of the Dutch Copyright Act, indicated by the "Taverne" license above, 


\title{
Integrative genomic analysis identifies a role for intercellular adhesion molecule 1 in childhood asthma
}

\author{
Ester M. M. Klaassen ${ }^{1}$, Kim D. G. van de Kant ${ }^{1}$, Quirijn Jöbsis ${ }^{1}$, John Penders ${ }^{2}$, \\ Frederik Jan van Schooten ${ }^{3}$, Marieke Quaak ${ }^{3,4}$, Gertjan J. M. den Hartog ${ }^{3}$, Gerard H. Koppelman ${ }^{5}$, \\ Constant P. van Schayck ${ }^{4}$, Guillaume van Eys ${ }^{6}$ \& Edward Dompeling ${ }^{1}$ \\ ${ }^{1}$ Department of Pediatric Pulmonology, School for Public Health and Primary Care (CAPHRI), Maastricht University Medical Centre (MUMC+), \\ Maastricht, the Netherlands; ${ }^{2}$ Department of Epidemiology, CAPHRI, MUMC+, Maastricht, the Netherlands; ${ }^{3}$ Department of Toxicology, School \\ for Nutrition, Toxicology, and Metabolism (NUTRIM), MUMC+, Maastricht, the Netherlands; ${ }^{4}$ Department of General Practice, CAPHRI, \\ MUMC+, Maastricht, the Netherlands; ${ }^{5}$ Department of Pediatric Pulmonology and Pediatric Allergology, Beatrix Children's Hospital, Groningen \\ Research Institute for Asthma and COPD (GRIAC), University of Groningen, University Medical Centre Groningen, Groningen, the Netherlands; \\ ${ }^{6}$ Department of Genetics and Cell Biology, Cardiovascular Research Institute (CARIM), MUMC+, Maastricht, the Netherlands
}

To cite this article: Klaassen EMM, van de Kant KDG, Jöbsis Q, Penders J, van Schooten FJ, Quaak M, den Hartog GJM, Koppelman GH, van Schayck CP, van Eys G, Dompeling E. Integrative genomic analysis identifies a role for intercellular adhesion molecule 1 in childhood asthma. Pediatr Allergy Immunol 2014 : 25: 166-172.

\begin{abstract}
Keywords
chemokine; cytokine; exhaled breath condensate; gene expression; genetic variants; intercellular adhesion molecule; single-nucleotide polymorphism; wheeze
\end{abstract}

\author{
Correspondence \\ Ester M. M. Klaassen, Department of \\ Pediatric Pulmonology, Maastricht University \\ Medical Centre, P.O. Box 58006202 AZ \\ Maastricht, the Netherlands \\ Tel.: +31433872944 \\ Fax: +31433875246 \\ E-mail: ester.klaassen@mumc.nl
}

Accepted for publication 3 December 2013

DOI:10.1111/pai.12187

\begin{abstract}
Background: Childhood asthma is characterized by chronic airway inflammation. Integrative genomic analysis of airway inflammation on genetic and protein level may help to unravel mechanisms of childhood asthma. We aimed to employ an integrative genomic approach investigating inflammation markers on DNA, mRNA, and protein level at preschool age in relationship to asthma development.

Methods: In a prospective study, 252 preschool children (202 recurrent wheezers, 50 controls) from the Asthma DEtection and Monitoring (ADEM) study were followed until the age of six. Genetic variants, mRNA expression in peripheral blood mononuclear cells, and protein levels in exhaled breath condensate for intercellular adhesion molecule 1 (ICAM1), interleukin (IL)4, IL8, IL10, IL13, and tumor necrosis factor $\alpha$ were analyzed at preschool age. At six years of age, a classification (healthy, transient wheeze, or asthma) was based on symptoms, lung function, and medication use.

Results: The ICAM1 rs5498 A allele was positively associated with asthma development $(\mathrm{p}=0.02)$ and ICAM1 gene expression $(\mathrm{p}=0.01)$. ICAM1 gene expression was positively associated with exhaled levels of soluble ICAM1 $(p=0.04)$ which in turn was positively associated with asthma development $(\mathrm{p}=0.01)$. Furthermore, rs1800872 and rs1800896 in IL10 were associated with altered IL10 mRNA expression $(\mathrm{p}<0.01)$. Exhaled levels of IL4, IL10, and IL13 were positively associated with asthma development $(\mathrm{p}<0.01)$.

Conclusions: In this unique prospective study, we demonstrated that ICAM1 is associated with asthma development on DNA, mRNA, and protein level. Thus, ICAM1 is likely to be involved in the development of childhood asthma.
\end{abstract}

Asthma is characterized by chronic airway inflammation and airway hyper-responsiveness which lead to symptoms such as wheeze $(1,2)$. However, wheezing symptoms at preschool age are mostly transient and caused by viral infections. Only around $30 \%$ of wheezing children at preschool age will have persistent symptoms and will ultimately develop asthma $(2,3)$. The exact mechanisms of childhood asthma are largely unclear and, therefore, it is not possible to distinguish true asthmatics from transient wheezers at preschool age (3).
We previously demonstrated that various levels of exhaled inflammation markers were elevated in children with preschool wheeze (4). However, in that cross-sectional analysis, we could not determine the role of these markers in relationship to asthma development. With an integrative genomic approach on DNA, mRNA, and protein level, the role of these markers can be further elucidated. Protein levels can be measured in exhaled breath condensate (EBC) with adequate sensitivity and reproducibility (5-7). Pro-inflammatory cytokines (T-helper 1 
cytokine tumor necrosis factor alpha (TNF $\alpha)$ and T-helper 2 cytokines interleukin (IL) 4 and IL13), an anti-inflammatory cytokine (IL10), a chemokine (IL8), and an adhesion molecule (Intercellular Adhesion Molecule 1 (ICAM1)) were selected for analysis. All these markers have previously been associated with childhood asthma and airway inflammation.

We hypothesize that when an inflammation marker is found to be associated with the development of asthma at the age of six, causal pathways can be inferred when the data are combined with DNA and RNA analysis (Fig. 1). The aim of our unique prospective study is to study inflammation markers in childhood asthma at gene coding, gene expression, and protein level.

\section{Methods}

\section{Study population}

The current study is conducted within the context of the Asthma DEtection and Monitoring (ADEM) study (8). A total of 202 children with recurrent wheeze ( $\geq 2$ episodes during life according to the ISAAC questionnaire) and 50 healthy controls (random selection of children without wheezing episodes during life) at 2-4 years of age were included (9). At preschool age, saliva or buccal cells (DNA), blood (RNA), and EBC were collected. If possible, the use of asthma medication was temporarily stopped prior to the measurement. In case of symptoms of an airway infection, the measurement was postponed. Ethical approval was obtained, and all parents provided written informed consent.

\section{Asthma diagnosis}

At the age of six, a classification (healthy, transient wheezer, or true asthmatic) was assessed by two pediatricians in the field of respiratory medicine based on recurrent wheeze at inclusion, current respiratory symptoms, lung function (reversibility to a $\mathrm{B}_{2}$ agonist and/or bronchial hyper-responsiveness according to the ERS guidelines) $(10,11)$, and the use of asthma medication. A challenge test was performed using histamine dissolved in physiologic saline in doubling concentrations from 0.032 to $16 \mathrm{mg} / \mathrm{ml}$. The classification 'healthy' was given when a child had no recurrent wheeze at time of inclusion and when asthma was not diagnosed at 6 years of age. The classification 'transient wheeze' was given when a child had recurrent wheeze at inclusion (defined as $\geq 2$ episodes during life according to the ISAAC questionnaire), but was not diagnosed with asthma at 6 years of age. The classification 'true asthmatic' was given when a child was diagnosed with asthma at 6 years of age. Additionally, this classification was compared with a computer algorithm as described previously (11). Mismatching cases were reassessed by a blinded pediatric pulmonologist who decided on the final classification.

\section{DNA isolation and genotyping}

Saliva was collected by Oragene DNA self-collection kits (Oragene $^{\circledR}$, Ottowa, ON, Canada). If children were unable to produce sufficient saliva, buccal cells were obtained. DNA was isolated according to the manufacturers' protocol. Participants were genotyped for seven single-nucleotide polymorphisms (SNPs) in six genes (see Table S1 electronic repository) based on previous association with childhood asthma, the ability to measure their product in EBC, and a minor allele frequency of at least $10 \%$. Six of the SNPs were determined using the massspectroscopy based, high-throughput MassARRAY ${ }^{\circledR}$ iPLEX $^{\circledR}$ platform (Sequenom ${ }^{\circledR}$ Inc., Hamburg, Germany) using two multiplex genotyping reactions. Primer and probe information are provided in Table S2 of the electronic repository. Rs2243250 could not be fitted into the multiplex reactions and was determined using the TaqMan ${ }^{\circledR}$ genotyping assay ID C_16176216_10 (Applied Biosystems, Carlsbad, CA, USA).

\section{RNA isolation and mRNA expression}

Total RNA was extracted from peripheral blood mononuclear cells (PBMCs) obtained by blood sampling. PBMCs were isolated with the Qiagen PaxGene Blood RNA kit (Qiagen ${ }^{\circledR}$, Hilden, Germany). cDNAs were generated by poly-A and random-primed reverse transcription with the accompanying Qiagen kit and used for the production of cRNA pools. Quantitative real-time PCR was performed using the Fluidigm BioMark system (AROS Applied Biotechnology, Aarhus, Denmark) to assess expression of the six selected genes (Table S1 electronic repository). A quality control was conducted based on slope and appearance of the amplification curve. An internal standard was obtained by computing the geometric mean of three housekeeping genes (GAPDH, Beta-actin,

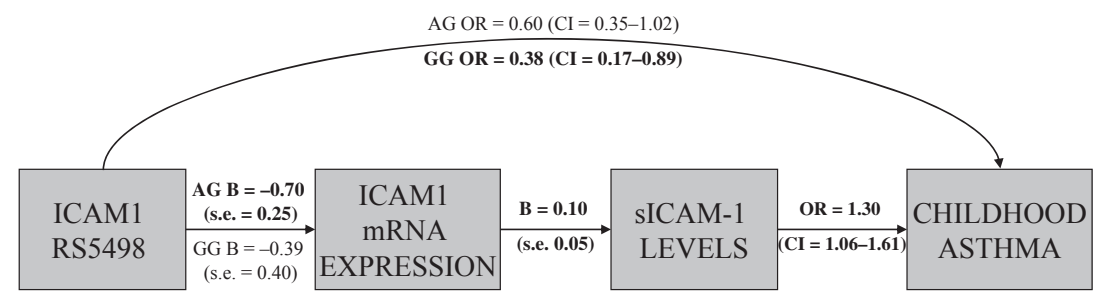

Figure 1 Summary of findings for ICAM1. The effect of genotype on gene expression and in turn on soluble ICAM1 levels in exhaled breath condensate with, as outcome, the development of asthma. Besides the direct effect of genotype on asthma development is shown. ICAM1, intercellular adhesion molecule 1; OR, odds ratio; Cl, 95\% confidence interval; AG, rs5498 genotype AG; GG, rs5498 genotype GG. Significant results $(p<0.05)$ are given in bold. 
Cyclophilin A) in each participant. For each selected gene, the cycle threshold $(\mathrm{Ct})$ value was adjusted by subtraction of the geometric mean according to this internal standard. In case two of the three housekeeping genes passed the quality control $(\mathrm{n}=11)$, the $\mathrm{Ct}$ value of the missing housekeeping gene was replaced by the mean $\mathrm{Ct}$ value of this gene within the study population.

\section{Inflammation markers in Exhaled Breath Condensate}

Exhaled breath condensate was collected using a closed glass condenser system with a breath recirculation unit developed at our institute $(6,8)$. Six inflammation markers in EBC (Table S1 electronic repository) were assayed using the multiplex immunoassay (Luminex ${ }^{\circledR}$ Corporation, Austin, TX, USA Utrecht) (12). In case of values under the detection limit, a randomly generated value was added using the uniform distribution between zero and the detection limit (13).

\section{Statistical analysis}

SPSS version 17.0 was used for data analysis (SPSS inc., Chicago IL, USA). Due to the skewed distributions, EBC markers were log-transformed which successfully imparted a normal distribution. For the relationship between individual SNPs and childhood asthma and the relationship between individual protein levels in EBC and childhood asthma, ordinal regression modeling adjusted for confounders (gender, age, passive smoking, and exposure to furry pets at home) was used. All SNPs were tested according to a co-dominant model (two major alleles $\neq$ one minor allele $\neq$ two minor alleles) or a dominant model when the minor allele genotype was present in $<10 \%$ of the participants. Linear regression was used for associations between SNPs and gene expression and associations between gene expression and inflammation markers in EBC. The condition at preschool age (recurrent wheeze or control) and confounders were included in the linear regression models. Results were expressed in adjusted odds ratio (OR) with $95 \%$ confidence interval $(95 \% \mathrm{CI})$ in case of logistic regression and adjusted $\mathrm{B}$ with standard error (s.e.) in case of linear regression. Differences were defined as significant when $\mathrm{p}<0.05$.

\section{Results}

\section{Baseline characteristics}

At preschool age, 252 children were included. Due to personal constraints of parents (e.g., lack of time or interest), four children were lost in the follow-up at 6 years of age. One child from the control group diagnosed with asthma was excluded from analysis. In total, 247 children were included in the analysis (76 asthmatics, 122 transient wheezers, and 49 healthy controls). The agreement between the computer algorithm classification and the clinical classification was high (91\%). Baseline characteristics are displayed in Table 1. Atopy, eczema, allergic rhinitis, and the use of asthma medication were significantly different between the groups, with the
Table 1 Baseline characteristics of the study population at preschool age

\begin{tabular}{|c|c|c|c|}
\hline Patient characteristics & $\begin{array}{l}\text { Healthy } \\
\text { controls } \\
(\mathrm{N}=49)\end{array}$ & $\begin{array}{l}\text { Transient } \\
\text { wheeze } \\
(\mathrm{N}=122)\end{array}$ & $\begin{array}{l}\text { Asthma } \\
(\mathrm{N}=76)\end{array}$ \\
\hline Mean age (s.d.), in years & $3.3(0.5)$ & $3.2(0.6)$ & $3.3(0.6)$ \\
\hline Gender: male/female, in N & $24 / 25$ & $63 / 59$ & $46 / 30$ \\
\hline Atopy, in $\% \dagger^{\prime *}$ & 23 & 17 & 37 \\
\hline Atopy first degree, in \%\$ & 65 & 79 & 79 \\
\hline Eczema, in \%* & 22 & 34 & 47 \\
\hline Allergic rhinitis, in $\%^{+, *}$ & 16 & 43 & 57 \\
\hline $\begin{array}{l}\text { White European descent, } \\
\text { in } \% \S\end{array}$ & 98 & 95 & 97 \\
\hline $\begin{array}{l}\text { Use of short-acting } B_{2} \\
\text { agonist, in \%* }\end{array}$ & 0 & 27 & 53 \\
\hline Use of ICS, in \%* & 0 & 11 & 30 \\
\hline $\begin{array}{l}\text { Day-care attendance, } \\
\text { in } \%\end{array}$ & 63 & 73 & 71 \\
\hline $\begin{array}{l}\text { Exposure to furry pets, } \\
\text { in } \%\end{array}$ & 55 & 46 & 46 \\
\hline Passive smoking, in \% & 35 & 30 & 30 \\
\hline Availability DNA, in \% & 100 & 100 & 100 \\
\hline Availability RNA, in \% & 84 & 92 & 88 \\
\hline Availability of EBC, in \% & 98 & 98 & 100 \\
\hline
\end{tabular}

s.d., standard deviation; EBC, exhaled breath condensate; N, number of children; ICS, inhaled corticosteroids.

$* p<0.05$.

$\dagger$ Atopy was defined as specific lgE concentration against a mixture of inhalant and food allergens of $\geq 0.35 \mathrm{kU} / \mathrm{l}$ on the Phadiatop Infant test ${ }^{\circledR}$ (Pharmacia, Uppsala, Sweden).

+Allergic rhinitis was based on the question 'In the past 12 months, has your child had a problem with sneezing or a runny or blocked nose when he/she did not have a cold of the flu?'

\$First degree relative with eczema, asthma, or allergic rhinitis. $\S$ White European descent was defined as at least 2 grandparents from white European descent.

highest frequencies in asthmatic children. Treatment of inhaled corticosteroids could not be stopped prior to measurement in six children. A sensitivity analysis excluding these children did not alter the results. An additional sensitivity analysis excluding non-white children $(n=10)$ did not alter the results either. Consequently, these children were kept in the analysis.

\section{Single-nucleotide polymorphisms in relationship to classification at age six and mRNA expression}

DNA extraction was successful in all children (100\%). All SNPs had a high call rate $(96.8-99.6 \%$, Table S1 electronic repository). No deviation from Hardy-Weinberg equilibrium was observed in the control group ( $p \geq 0.05$, Table $\mathrm{S} 1$ electronic repository). Furthermore, linkage disequilibrium was calculated $\left(R^{2}=0.27\right.$ for IL10 rs1800872 and rs1800896).

Regarding the relationship between SNPs and the classification at age six, the ICAMI rs5498 AA genotype was associated with an increased likelihood of childhood asthma compared to the AG genotype $(\mathrm{p}=0.02$, Table 2, Fig. 1). For 
Table 2 Association between single-nucleotide polymorphisms (SNPs) and the development of childhood asthma

\begin{tabular}{lllrlll}
\hline Gene & rs-number & Genotype & $N$ & OR* & $95 \%$ Cl & p-value \\
\hline IL4 & rs2243250 & CC & 175 & ref & & \\
& & CT/TT & 64 & 1.70 & $0.98-2.93$ & 0.06 \\
IL8 & rs2227306 & CC & 89 & ref & & \\
& & CT & 119 & 1.11 & $0.66-1.86$ & 0.70 \\
& & TT & 35 & 0.53 & $0.25-1.13$ & 0.10 \\
IL10 & rs1800872 & GG & 131 & ref & & \\
& & GT/TT & 115 & 0.80 & $0.50-1.28$ & 0.35 \\
& rs1800896 & TT & 75 & ref & & \\
& & TC & 122 & 0.89 & $0.52-1.53$ & 0.67 \\
& & CC & 48 & 0.91 & $0.46-1.81$ & 0.79 \\
IL13 & rs1800925 & CC & 144 & ref & & \\
& & CT/TT & 99 & 1.44 & $0.89-2.35$ & 0.14 \\
TNF $\alpha$ & rs1800629 & GG & 174 & ref & & \\
& & GA/AA & 72 & 1.13 & $0.67-1.90$ & 0.66 \\
ICAM1 & rs5498 & AA & 81 & ref & & \\
& & AG & 137 & 0.60 & $0.35-1.02$ & 0.06 \\
& & GG & 27 & 0.38 & $0.17-0.89$ & $\mathbf{0 . 0 2}$ \\
\hline
\end{tabular}

$\mathrm{N}$, number of children; $\mathrm{OR}$, odds ratio; $95 \% \mathrm{Cl}, 95 \%$ confidence interval; ref., reference category; IL, interleukin; TNF $\alpha$, tumor necrosis factor alpha; ICAM1, intercellular adhesion molecule 1. *Adjusted for gender, age, passive smoking, and exposure to furry pets.

Values in bold are statistically significant, $\mathrm{p}<0.05$.

the relationship between SNPs and their respective gene expression, we found that the AG genotype of ICAMI rs5498 $(\mathrm{p}=0.01)$ and the minor allele of IL10 rs1800896 $(\mathrm{p}<0.01)$ were negatively associated with their mRNA expression levels, whereas the minor allele of IL10 rs1800872 $(\mathrm{p}<0.01)$ was positively associated with IL10 mRNA expres-

Table 3 Association between single-nucleotide polymorphisms (SNPs) and mRNA expression at preschool age

\begin{tabular}{lllrlll}
\hline Gene & rs-number & Genotype & $N$ & B* & s.e. & p-value \\
\hline IL8 & rs2227306 & CC & 79 & ref & & \\
& & CT & 106 & 0.04 & 0.20 & 0.86 \\
& & TT & 34 & -0.45 & 0.28 & 0.11 \\
IL10 & rs1800872 & TT & 117 & ref & & \\
& & TG/GG & 105 & 0.83 & 0.16 & $<\mathbf{0 . 0 1}$ \\
& rs1800896 & TT & 67 & ref & & \\
& & TC & 111 & -0.58 & 0.19 & $<\mathbf{0 . 0 1}$ \\
& & CC & 43 & -1.06 & 0.23 & $<\mathbf{0 . 0 1}$ \\
TNFa & rs1800629 & GG & 159 & ref & & \\
& & GA/AA & 63 & -0.18 & 0.22 & 0.41 \\
ICAM1 & rs5498 & AA & 74 & ref & & \\
& & AG & 122 & -0.70 & 0.25 & $\mathbf{0 . 0 1}$ \\
& & GG & 25 & -0.39 & 0.40 & 0.34 \\
\hline
\end{tabular}

$N$, number of children; $B$, regression coefficient; s.e., standard error; ref., reference category; IL, interleukin; TNF $\alpha$, tumor necrosis factor alpha; ICAM1, intercellular adhesion molecule 1.

*Adjusted for group at preschool age, gender, age, passive smoking, and exposure to furry pets.

Values in bold are statistically significant, $p<0.05$. sion levels (Table 3, Fig. 1). Although the GG genotype did not demonstrate a statistically significant relationship with ICAM1 mRNA expression, the direction (negative) of the relationship was the same as for the AG genotype. The relationship between IL4 and IL13 polymorphisms and their gene expression was not assessed, as expression was only detected in a small number of samples $(n=23$ and $n=44$, respectively). Alternatively, the direct effect of IL4 and IL13 polymorphisms on levels of IL4 and IL13 in EBC was analyzed, but did not show any significant association ( $\mathrm{p}>0.05$, data not shown).

mRNA expression in relationship to exhaled breath condensate levels

In 25 children, no RNA samples were obtained as these children refused venous puncture. The mRNA expression markers could be determined in $91-95 \%$ of the samples. A significant positive association was seen for ICAM1 mRNA expression level with the concentration of sICAM1 in EBC $(\mathrm{p}=0.04$, Table 4, Fig. 1).

\section{Levels in exhaled breath condensate in relationship to classification at age six}

Inflammation markers in EBC were successfully analyzed in all but three children due to technical problems. EBC markers were above the detection limit in more than $98 \%$ of the samples. sICAM1 (Fig. 1), IL4, IL10, and IL13 were significantly positively associated with the risk to develop asthma $(\mathrm{p}=0.01, \mathrm{p}<0.01, \mathrm{p}<0.01, \mathrm{p}<0.01$, respectively, Table 5).

\section{Discussion}

In this prospective study, we examined associations between SNPs, gene expression levels in PBMCs, and protein levels in $\mathrm{EBC}$ for various inflammation markers at preschool age in relationship to the risk of developing asthma at the age of six. ICAM1 has previously been shown to play a central role in the recruitment and migration of leukocytes to sites of inflammation and has been linked to childhood asthma (5, 14-17). In this study, the ICAM1 rs5498 A allele was found to be

Table 4 Association between mRNA expression and inflammation markers in $\mathrm{EBC}$ at preschool age

\begin{tabular}{lllll}
\hline Gene & N & B* & s.e. & p-value \\
\hline IL8 & 210 & 0.05 & 0.06 & 0.33 \\
IL10 & 204 & 0.02 & 0.07 & 0.77 \\
TNF $\alpha$ & 201 & 0.02 & 0.05 & 0.72 \\
ICAM1 & 210 & 0.10 & 0.05 & $\mathbf{0 . 0 4}$ \\
\hline
\end{tabular}

$\mathrm{N}$, number of children; $\mathrm{B}$, regression coefficient; s.e., standard error; IL, interleukin; TNF $\alpha$, tumor necrosis factor alpha; ICAM1, intercellular adhesion molecule 1.

*Adjusted for group at preschool age, gender, age, passive smoking, and exposure to furry pets.

Values in bold are statistically significant, $p<0.05$. 
Table 5 Association between inflammation markers in exhaled breath condensate (EBC) at preschool age and the development of childhood asthma

\begin{tabular}{llllr}
\hline Marker & N & OR* & $95 \% \mathrm{Cl}$ & p-value \\
\hline IL4 & 244 & 1.42 & $1.11-1.83$ & $\mathbf{< 0 . 0 1}$ \\
IL8 & 244 & 1.26 & $1.00-1.57$ & 0.05 \\
IL10 & 244 & 1.43 & $1.15-1.78$ & $<\mathbf{0 . 0 1}$ \\
IL13 & 244 & 1.42 & $1.12-1.81$ & $<\mathbf{0 . 0 1}$ \\
TNF $\alpha$ & 244 & 1.02 & $0.81-1.29$ & 0.85 \\
SICAM1 & 244 & 1.30 & $1.06-1.61$ & $\mathbf{0 . 0 1}$ \\
\hline
\end{tabular}

$\mathrm{N}$, number of children; OR, odds ratio; $95 \% \mathrm{Cl}, 95 \%$ confidence interval; IL, interleukin; TNF $\alpha$, tumor necrosis factor alpha; sICAM1, soluble intercellular adhesion molecule 1.

*Adjusted for gender, age, passive smoking, and exposure to furry pets.

Values in bold are statistically significant, $p<0.05$.

associated with increased mRNA expression of this gene and an increased likelihood of developing asthma. Association of the A allele with asthma has previously been reported (14), although the $\mathrm{G}$ allele has also been associated with asthma (18). Moreover, we demonstrated that increased ICAMI mRNA levels were associated with increased levels of sICAM1 in EBC, and higher levels of sICAM1 were in turn associated with an increased risk for asthma development. Furthermore, levels of IL4, IL10, and IL13 in EBC were positively associated with the risk to develop asthma. A potential mechanism is that increased expression and levels of sICAM1 might lead to an increased binding of leukocytes and thereby increased production of inflammation. Taken together, our study indicates that ICAM1 is a significant marker of and may be involved in childhood asthma development.

The ICAM1 polymorphism rs $5498 \mathrm{G}$ allele results in an amino acid change in exon 6 (K469E). The domain in the protein to which this amino acid belongs is subject to debate. According to one study, the rs5498 polymorphism is located in the membrane-spanning region, causing a shift in electrical charge, which may influence anchorage in the membrane, thereby affecting the ability to bind inflammatory cells (19). This disagrees with other studies stating that rs5498 is located outside the membrane (20-22). It has been hypothesized that this polymorphism can influence protein-protein dimerization and consequently alters the ability to bind inflammatory cells $(23,24)$. Moreover, the rs5498 polymorphism might make ICAM1 more prone to enzymatic cleavage (21). This may result in an increased generation of the soluble form of ICAM1, which could decrease the binding ability of leukocytes. On the other hand, the presence of the A allele has been shown to lead to alternative splicing, also resulting in an increased formation of sICAM1 (23). Overall, these data suggest that the rs5498 polymorphism in ICAM1 may play a role in the development of airway inflammation by decreasing the binding capacity of leukocytes. This is in line with data obtained in animal models, in which the absence of ICAM1 caused reduced leukocyte influx and consequently decreased airway hyper-reactivity (25).
We demonstrated that the ICAMI mRNA concentration was increased among subjects with the ICAM1 rs5498 AA genotype. This increased concentration may be due to either linkage of rs5498 with a SNP in the promoter region, a decreased degradation of the mRNA, or a reduced feedback mechanism due to alternative splicing and/or generation of sICAM1. Remarkable in this respect is the positive relationship we have found between ICAM1 mRNA concentration and levels of sICAM1 in EBC as several processes during translation and post-modification can influence protein level. Furthermore, raised ICAM1 mRNA and raised sICAM1 levels have been measured in different compartments. It is conceivable that increased mRNA concentrations lead to a higher expression of ICAM1 on the leukocyte cell membrane. This increased expression is, in turn, expected to enhance the binding of leukocytes to the affected lung epithelium, thereby increasing the number of local leukocytes. Consequently, the total production of inflammation markers might be increased due to the increased number of leukocytes. This can explain the higher levels of interleukins and sICAM1 detected in $\mathrm{EBC}$ of asthmatics. Increased levels of interleukins and sICAM1 in EBC have also been reported previously in asthmatic children $(5,26)$.

We found that no association between the studied IL10 polymorphisms and asthma development was observed in our study, which is in contrast with previous studies $(27,28)$. However, we did provide evidence that gene expression of IL10 is decreased in the presence of at least one rs1800896 C allele and increased in the presence of at least one rs1800872 $\mathrm{G}$ allele. However, gene expression of IL10 was not related to levels of IL10 in EBC. Nevertheless, in our study, the levels of IL10 in EBC were positively associated with asthma development. Previous research has demonstrated low levels of IL10 in plasma of asthmatic children, but IL10 in EBC did not differ between healthy controls and asthmatics in other studies $(5,6$, 29). As stated before, the relationship between increased IL10 levels and asthma development might be a consequence of the presence of more leukocytes and consequently increased inflammation in the lung tissue, and as such is related to sICAM1 levels.

A major strength of the present study is that we have prospectively studied inflammation markers in childhood asthma at gene coding, gene expression, and protein level with a unique approach. Furthermore, we used a noninvasive and feasible method to measure airway inflammation using markers in EBC. Although this technique seems to be sensitive and reproducible, more research is required before implementation in daily practice is possible (5-7). The high follow-up rate $(98 \%)$ and our diagnostic approach provided us with a well-defined study population. Moreover, the use of ordinal regression permitted us to observe the relationship of inflammation markers with childhood asthma in three different groups with increasing severity of symptoms.

However, some limitations need to be taken into account. A limitation of the current study is that, due to ethical considerations, it was not possible to measure expression of ICAM1 on the cell membrane of local leukocytes in the lungs. 
Consequently, the mRNA samples are at best a reference for the overall status of the immune system and therefore also of the lungs. Another possible limitation of our study is that we have not corrected for multiple testing. It should be noted that none of the associations would have remained significant after correction. However, our ICAM1 associations were present on each tested level. The unequivocalness of these findings points to an actual association. Finally, we restricted our analysis to polymorphisms with a minor allele frequency of $10 \%$ or higher. Consequently, we were not able to analyze rare variants. Thus, some associations with rare variants could have been missed.

In summary, in this study, we have investigated the role of SNPs, gene expression, and protein levels in EBC of inflammation markers at preschool age in relationship to asthma development at 6 years of age. Our results suggest a significant role of ICAM1 in the development of childhood asthma. We demonstrated an adverse effect for the ICAM1 rs5498 A allele which is associated with an increased expression of ICAM1
mRNA, and in turn increased sICAM1 levels in EBC. This might lead to an increased binding of leukocytes and thereby an increased production of inflammatory markers, ultimately leading to the development of asthma.

\section{Acknowledgments}

We thank Prof. Dr. J. Leunissen for his advice concerning the protein structure of ICAM1; Ger Rijkers, Shufan Qi, Patrick van Gorp, and Daniëlle Pachen for their skilled assistance with the laboratory procedures; medical students Imke Duijf, Kiki Vangangelt, Nedim Dzino, Brenda Thönissen, Esther Kalicharan, and Emily Cohen for their outstanding assistance during the measurements; and all parents and children who participated in the study.

\section{Conflict of interests}

None of the authors have any conflict of interests to declare.

\section{References}

1. Bisgaard H, Szefler S. Prevalence of asthmalike symptoms in young children. Pediatr Pulmonol 2007: 42: 723-8.

2. Pedersen SE, Hurd SS, Lemanske RF Jr, et al. Global strategy for the diagnosis and management of asthma in children 5 years and younger. Pediatr Pulmonol 2011: 46: $1-17$.

3. Savenije OE, Granell R, Caudri D, et al. Comparison of childhood wheezing phenotypes in 2 birth cohorts: ALSPAC and PIAMA. J Allergy Clin Immunol 2011: 127: 1505-12 e14.

4. van de Kant KD, Klaassen EM, Jöbsis Q, et al. Wheezing in preschool children is associated with increased levels of cytokines/ chemokines in exhaled breath condensate. $J$ Allergy Clin Immunol 2010: 126: 669-71.

5. Robroeks CM, Rijkers GT, Jöbsis Q, et al. Increased cytokines, chemokines and soluble adhesion molecules in exhaled breath condensate of asthmatic children. Clin Exp Allergy 2010: 40: 77-84.

6. Rosias PP, Robroeks CM, van de Kant $\mathrm{KD}$, et al. Feasibility of a new method to collect exhaled breath condensate in preschool children. Pediatr Allergy Immunol 2010: 21: e235-44.

7. Hunt J. Exhaled breath condensate: an evolving tool for noninvasive evaluation of lung disease. J Allergy Clin Immunol 2002: 110: $28-34$.

8. van de Kant KD, Klaassen EM, Jöbsis Q, Nijhuis AJ, van Schayck OC, Dompeling E. Early diagnosis of asthma in young children by using non-invasive biomarkers of airway inflammation and early lung function measurements: study protocol of a case-control study. BMC Public Health 2009: 9: 210.

9. Worldwide variation in prevalence of symptoms of asthma, allergic rhinoconjunctivitis, and atopic eczema: ISAAC. The International Study of Asthma and Allergies in Childhood (ISAAC) Steering Committee. Lancet 1998; 351: 1225-32.

10. Miller MR, Hankinson J, Brusasco V, et al. Standardisation of spirometry. Eur Respir $J$ 2005: 26: 319-38.

11. Klaassen EM, van Kant KD, Jöbsis Q, et al. Symptoms, but not a biomarker response to inhaled corticosteroids, predict asthma in preschool children with recurrent wheeze. Mediators Inflamm 2012: 2012: 162571.

12. de Jager W, te Velthuis H, Prakken BJ, Kuis W, Rijkers GT. Simultaneous detection of 15 human cytokines in a single sample of stimulated peripheral blood mononuclear cells. Clin Diagn Lab Immunol 2003: 10: 133-9.

13. van de Kant KD, Koers K, Rijkers GT, et al. Can exhaled inflammatory markers predict a steroid response in wheezing preschool children? Clin Exp Allergy 2011: 41: 1076-83.

14. Li YF, Tsao YH, Gauderman WJ, et al. Intercellular adhesion molecule-1 and childhood asthma. Hum Genet 2005: 117: 476-84.

15. Vogel SM, Orrington-Myers J, Broman M, Malik AB. De novo ICAM-1 synthesis in the mouse lung: model of assessment of protein expression in lungs. Am J Physiol Lung Cell Mol Physiol 2006: 291: L496-501.
16. Keramidaris E, Merson TD, Steeber DA, Tedder TF, Tang ML. L-selectin and intercellular adhesion molecule 1 mediate lymphocyte migration to the inflamed airway/lung during an allergic inflammatory response in an animal model of asthma. $J$ Allergy Clin Immunol 2001: 107: 734-8.

17. Montefort S, Holgate ST. Adhesion molecules and their role in inflammation. Respir Med 1991: 85: 91-9.

18. Puthothu B, Krueger M, Bernhardt M, Heinzmann A. ICAM1 amino-acid variant $\mathrm{K} 469 \mathrm{E}$ is associated with paediatric bronchial asthma and elevated sICAM1 levels. Genes Immun 2006: 7: 322-6.

19. Bella J, Kolatkar PR, Marlor CW, Greve JM, Rossmann MG. The structure of the two amino-terminal domains of human ICAM-1 suggests how it functions as a rhinovirus receptor and as an LFA-1 integrin ligand. Proc Natl Acad Sci US A 1998: 95: 4140-5.

20. Staunton DE, Marlin SD, Stratowa C, Dustin ML, Springer TA. Primary structure of ICAM-1 demonstrates interaction between members of the immunoglobulin and integrin supergene families. Cell 1988: 52: 925-33.

21. Robledo O, Papaioannou A, Ochietti B, et al. ICAM-1 isoforms: specific activity and sensitivity to cleavage by leukocyte elastase and cathepsin G. Eur J Immunol 2003: 33: 1351-60.

22. Jun CD, Shimaoka M, Carman CV, Takagi J, Springer TA. Dimerization and the effectiveness of ICAM-1 in mediating LFA1-dependent adhesion. Proc Natl Acad Sci U $S$ A 2001: 98: 6830-5. 
23. Iwao M, Morisaki H, Morisaki T. Singlenucleotide polymorphism g. $1548 \mathrm{G}>\mathrm{A}$ (E469K) in human ICAM-1 gene affects mRNA splicing pattern and TPA-induced apoptosis. Biochem Biophys Res Commun 2004: 317: 729-35.

24. Casasnovas JM, Stehle T, Liu JH, Wang JH, Springer TA. A dimeric crystal structure for the N-terminal two domains of intercellular adhesion molecule-1. Proc Natl Acad Sci U S A 1998: 95: 4134-9.
25. Tang ML, Fiscus LC. Important roles for L-selectin and ICAM-1 in the development of allergic airway inflammation in asthma. Pulm Pharmacol Ther 2001: 14: 203-10.

26. Tang RB, Chen SJ, Soong WJ, Chung RL. Circulating adhesion molecules in sera of asthmatic children. Pediatr Pulmonol 2002: 33: 249-54.

27. Hunninghake GM, Soto-Quiros ME, Lasky-Su J, et al. Dust mite exposure modifies the effect of functional IL10 polymorphisms on allergy and asthma exacerbations. J Allergy Clin Immunol 2008: 122: 93-8, 98 e1-5.

28. Lyon H, Lange C, Lake S, et al. IL10 gene polymorphisms are associated with asthma phenotypes in children. Genet Epidemiol 2004: 26: 155-65.

29. Zheng XQ, Li CC, Xu DP, et al. Analysis of the plasma soluble human leukocyte antigen-G and interleukin-10 levels in childhood atopic asthma. Hum Immunol 2010: 71: $982-7$.

\section{Supporting Information}

Additional Supporting Information may be found in the online version of this article:
Table S1. Markers included in the current study

Table S2. Primer sequences used for genotyping by Sequenom 